\title{
A Comparative Study of Financial Dialectics and Economic Value Added vs. Traditional Profit based Measures: a case study at BHEL-Electro Porcelains Division (EPD)
}

\author{
${ }^{1}$ Ms. Shalini H. S., ${ }^{2}$ Ms. Preethi V. S. \\ ${ }^{1}$ Surana College - Centre for Post Graduate Studies, Bangalore ${ }^{2}$ PESIT South Campus, Bangalore
}

\begin{abstract}
Companies which earn higher returns than overall cost of capital for their shareholders are preferred by the shareholders than those which earn lower return than overall cost of capital. In fact these companies are deemed destroyers of shareholder's value. This research paper examines the effectiveness of economic value added method over the other traditional methods which were used to analyze the financial position of an enterprise. To evaluate this, some important traditional performance measures such as return on capital employed(ROCE), return on equity(ROE) along with a new performance measure called Economic value added (EVA) have been used. Extensive research studies have demonstrated that the traditional financial performance parameters are not adequate. Instead this new concept is growing fast and is being used to evaluate the overall financial performance of corporate entities.
\end{abstract}

Keywords -Cost of capital (COC), Economic value addition (EVA), Market value addition (MVA), Net operating profit after taxes (NOPAT), Return on capital employed (ROCE)

\section{INTRODUCTION}

Economic Value Added (EVA) is the difference between the company's net operating profits after taxes and the cost of capital employed in generating those profits in a financial year. If EVA is positive the company creates shareholder's wealth and if the EVA is negative then the shareholder's wealth is destroyed.

\subsection{BACKGROUND OF THE STUDY:}

The present age of globalization, has led to a revolutionary change in the criteria of financial performance measurement. The whole world has witnessed the influence of researches being undertaken in the different fields. The nature of the discourse regarding the measurement and evaluation of corporate Performance has broadened in recent years with the adoption of different perspectives (Crowther 1996). Deficiencies and limitations of past researches create the need for advanced researches. Beaver (1989) states that there has been a shift from an economic view of corporate performance measurement to an informational perspective with recognition of the social implications of organization's activities. Similarly Eccles (1991) states that there has been a shift from treating financial figures as the foundation of corporate performance measurement to treating them as part of a broader range of measures, while McDonald and Puxty (1979) maintain that companies are no longer the instruments of shareholders alone but exist within society and so have responsibilities to that society. Others (eg Tinker 1985) argue for a changed basis for accounting to reflect these changes.

The discourse therefore seems to have moved away from the concerns of shareholders in the firm and away from the economic rationale for accounting towards a consideration of the wider stakeholder environment. At the same time however these concerns cannot be ignored and part of the discourse has seen a return to economic values in assessing the performance of the firm. Thus Rappaport (1986) recognizes some of the problems with accounting, such as the exclusion of risk and investment policies from the analysis but goes on to consider the concept of shareholder value and how this can be created and sustained. He develops a methodology of shareholder value, arguing (1992) that a shareholder value approach is the correct way of evaluating alternative company strategies, stating that the ultimate test of a corporate plan is whether it creates value for the shareholders, and that this is the sole method of evaluating performance. He identifies a conflict between the achievement of competitive advantage and creating shareholder value when he states:

"Increasingly, companies are becoming polarized into two camps: those who consider shareholder value the key to managing the company and those who put their faith in gaining competitive advantage." (P 85) but argues that both are based upon long term productivity.

The return to a consideration of the importance of economic value to the theory of the firm is based upon the assumption that maximizing the value of a firm to its shareholders also maximizes the value of that firm to society at large. Within the discourse therefore the concept of shareholder value is frequently mentioned and there is acceptance of the need to account for shareholder value within the practitioner community. Indeed 
the annual reports of companies regularly report the creating of value for shareholders and it is frequently cited as a corporate objective. What is less clear however from an examination of such annual reports is precisely what is meant by this creation of shareholder value, which often seems to be used in a nebulous manner to indicate some desirable but unidentifiable objective. The concept of shareholder value as an objective therefore appears to be widely accepted within the accounting community but its use as a quantified evaluation is less often found in practice. This, it is argued, is because the managers of a firm are preoccupied with other objectives such as growth in size, turnover, market share or accounting returns, which are more easily measured. The achievement of these objectives is also often correlated with managerial rewards but less so with increasing shareholder value (Williamson 1963). Indeed Jensen and Meckling (1976) use agency theory to demonstrate how following managerial interests can lead to higher rewards for those managers at the expense of a reduction in the value of the company. Problems arise from the use of accounting measures as a means of evaluating company performance, and Stewart (1991) and Brealy and Myers (1991) separately consider how the use of earnings per share can be of doubtful value in achieving this end, both because of the different calculations used for the same accounting measure and because of the adoption of different accounting measures, while Fisher and McGowan (1983) show that ROI, ROA and ROE suffer from the same problem.

Extensive research studies have demonstrated that the traditional financial performance parameters such as return on capital employed, return on equity and earning per share etc. are not adequate; hence a new concept called Economic Value Added is growing fast and is being used to evaluate the overall financial performance of corporate entities. According to this concept, all such companies that earn lower returns than overall cost of capital are deemed destroyers of shareholder value.

As rightly observed by management guru Peter Drucker, "EVA is based on something we have known for a long time- what we call profit, the money left to service equity, is usually not profit at all. Until a business returns a profit greater than its overall cost of capital, it operates at a loss. Never mind it pays taxes as if it had a genuine profit. The enterprise returns less to the economy than it devours in resources. Until then it does not create wealth, it destroys it." The use of quantitative analysis has become increasingly important in the era of globalization and liberalization due to fast moving technology and increasing complexities in business and industry. The quantitative techniques are now considered as an effective aid towards solving management problems. Business executives and others concerned with management responsibilities are supposed to have a good knowledge of quantitative techniques, particularly in modern competition business world.

\subsection{Theoretical framework of EVA:}

It is a performance metric that calculates the creation of shareholder value. It distinguishes itself from traditional financial performance metrics such as net profit and EPS. EVA is the calculation of what profits remain after the costs of a company's capital- both debt and equity, - are deducted from operating profit. The idea is simple but rigorous: true profit should account for the cost of capital. In other words, EVA charges the company rent for typing up investor's cash to support operations. There is a hidden opportunity cost that goes to investors to compensate them for forfeiting the use of their own cash. EVA captures this hidden cost of capital that conventional measures ignore.

Literally, EVA is the quantum of economic value (or profits) generated by a company in excess of its cost of capital (COC). Mathematically, it is the difference between the net operating after taxes (NOPAT) and the capital changes; or, the product of the capital employed and the difference between the Return on capital employed (ROCE) and the COC. In principle, it is a comprehensive financial management system then encompasses a range of function like capital budgeting, acquisition pricing, goal-setting, and strategic planning. In accounting terms, the concept of EVA is based on the principle of residual income which states that the real income generated by a company is the residue that remains after a company's shareholders and debtors have been paid their annual required return. However, even traditional accounting is based on the residual income. Principle the profits after tax (PAT) is the residual income after the payment of interest and dividend. Economic value added (EVA) is the financial performance method to calculate the true economic profit of a corporation. EVA can be calculated as net operating after taxes profit minus a charge for the opportunity cost of the capital invested.

EVA is an estimate of the amount by which earnings exceed or fall short of the required minimum rate of return for shareholders or lenders at comparable risk. Unlike market-based measures, such as EVA, MVA can be calculated at divisional (strategic unlike stock measures. EVA is a flow and can be used for performance evaluation over time. Unlike accounting profit, such as EBIT, net income and EPS, EVA is economic and is based on the idea that a business must cover both the operating costs and the capital costs.

The VBM concept which seems to have received most interest is the EVA approach, which has been advocated (Stewart 1991) as a better measure to assess corporate performance and the creation of shareholder value than conventional accounting measures. Indeed Stewart (1994) states that:"Economic value added is an estimate, however simple or precise, of a business's true economic profit.” (P 73)

Economic value added is claimed to have a number of important advantages over traditional 
accounting measures, the chief one being that economic performance is only determined after the making of a risk adjusted charge for the capital employed in the business. Critics however argue that while this may be theoretically sound, the need to make arbitrary adjustments to standard accounting numbers in order to put the technique into practice makes the technique of doubtful validity. The application of the technique and the adjustments needed were evaluated by Coates, Davies, Davis, Zafar and Zwirlein (1995) who suggest that simplified calculations produce satisfactorily reliable results. This paper uses a study of BHEL-EPD in order to evaluate the technique in practice and to consider some of the limitations of the technique in assessing the performance of this company.

\subsection{The Use of Traditional Accounting as a Measure of Shareholder Value:}

Traditionally, performance measurement and reward systems have been based on accounting numbers such as EPS and ROCE. A number of authors have criticized such measures for promoting a short-term focus for managerial actions (eg Ezzamel and Hart, 1987; Rappaport, 1986). Rappaport also argues that accounting profit fails to measure changes in the economic value of the firm, citing the following reasons:

- alternative accounting methods can be employed

- risk is excluded

- investment requirements are excluded

- dividend policy is not considered

- the time value of money is ignored

Despite these limitations, there is a widespread belief in the UK and the US that share prices are driven by the capitalization of a company's earnings per share at an appropriate price/earnings ratio multiple (e.g. Stewart, 1991). A number of writers have described an apparent 'fixation' with EPS, and Rappaport (1986), states, '...In both corporate reports and the financial press, there is an obsessive fixation on earnings per share (EPS) as the scorecard of corporate performance'.

In the UK, a survey by $3 \mathrm{i}$ in 1990 found that '...81\% (of UK finance directors) believed that EPS was the main basis for the valuation of share prices'. The Accounting Standards Board have sought to reduce the emphasis placed on earnings per share, primarily through Financial Reporting Standard 3 (FRS 3), 'Reporting Financial Performance', which required a number of changes to the presentation of the profit and loss account as well as the calculation of earnings per share and the definition of extraordinary items. FRS 3 states:

'It is not possible to distill the performance of a complex organizationinto a single measure. Undue significance, therefore, should not be placed on any one such measure which may purport to achieve this aim'. (para. 52)

However, soon after FRS 3 was published the Institute for Investment Management and Research (IIMR) published guidance under which 'maintainable EPS' could be calculated. The IIMR argued that this 'maintainable EPS' statistic was the key indicator of corporate performance, providing further evidence of the EPS fixation. More recently, a Sunday Times survey of the top 200 UK companies, carried out in conjunction with Braxton Associates, found that most companies are still using EPS as the key target for guiding their businesses (Sunday Times, August 11, 1996).

The popularity of share option schemes and profit-related bonus schemes for top management combined with the EPS fixation means that EPS is a widely adopted performance measure in the UK. However, Stewart (1991) and Rappaport (1986) emphasize that there is only a limited relationship between EPS and value creation by a company. VBM approaches, on the other hand, are claimed to offer a superior means of promoting wealth creating corporate behavior. In the next part of the paper, the performance of BHEL-EPD is again analyzed, this time using the Stern Stewart EVA and MVA approach.

\subsection{FIANANCIAL STATEMENTS:}

"Financial statements are prepared for the purpose of presenting a periodical review or report on the progress by the management and deal with:

(a) The status of investment in the business and

(b) The result achieved during a period under review".

The statement disclosing status of investment is known as balance sheet and the statement showing the result is known as profit and loss account. A firm communicates financial information to the users through financial statements and reports, the financial statements contain summarized information of the firm's financial affairs, organizes systematically. They are means to present the firm's financial situation to users; the preparation of financial statement is the responsibility of top management.

The two basic financial statements prepared for the purpose are the two statements, that is, balance sheet and the profit and loss account, as these statements are used by investors and financial analyst to examine the firm's performance in order to make investment decisions.

Recently a number of schedules are also being used to supplement the data and information contained in the above statement. Thus, Schedules of Fixed Assets, Schedule of Debtors, Schedule of Creditors, Schedule of Reserves, etc, are some of the schedules which are generally attached to the statement, The Schedules are 
considered as part of the statements for the purpose of analysis and in fact, they constitute the first step towards the analysis of certain data in financial statements. The financial statements are prepared from the accounting records maintained by the firm.

\subsection{BALANCE SHEET:}

Balance sheet comprises of a list of Assets, Liabilities and Capital at a given date. It is static in character because it tells about the financial position of a business as on a certain date. At the same time business is dynamic while balance sheet is static, it records only periodic changes just rather than continuous changes. More specifically balance sheet contains information about resources and obligation for business entity and about owner's interest in the business at a particular point of time.

In a simple language, A balance sheet may be called as statement of equation in which equality is established by representing asset values on one side and values of liabilities and the owner's fund on the other side of it. "The balance sheet is a statement which reports the property's value-owned by the enterprise and the claims of the creditors and owners against these properties". The amount of value is obtained by posting and balancing the individual accounts of each item.

Basic division of balance sheet are as follows:

\begin{tabular}{|ll|ll|}
\hline \multicolumn{2}{|c|}{ ASSETS } & \multicolumn{2}{l|}{ LIABILITIES } \\
\hline 1. & Current assets & 1. & Current liabilities. \\
\hline 2. & Fixed assets & 2. & Non-current liabilities. \\
\hline 3. & Intangible assets & 3. & Net worth \\
\hline 4. & Other assets & & \\
\hline 5. & Deferred expenditure & & \\
\hline
\end{tabular}

\subsection{BALANCE SHEET EQUATION:}

Both the sides of the balance sheet should be equal, i.e.; assets must be equal to liabilities plus owners capital. We can express this equation of the balance sheet in an equation form:

Total assets $=$ Total liabilities + Owners equity.

Owners fund $=$ total assets - total liability.

We can obtain more equations if we elaborate the above equation:

Liquid assets $=$ current assets - stock of all types.

Working capital $=$ current assets - current liabilities.

Capital employed $=$ total assets - current liabilities.

\subsection{PROFIT AND LOSS ACCOUNT:}

The Profit and Loss account is the score board of the firm's performance during a particular period of time. The Profit and Loss account presents the summary of revenues, expenses and net income or net loss of a firm for a period of time. It serves as a measure of the firm's profitability. Net income which is as indicator of the firm's profitability operation is the amount by which the revenues earned during the period excess the expenses incurred during that period.

The Profit and Loss account may also be called by various names, such as;

- Statement of Income and earned surpluses.

- Income statement.

- Statement of Revenue and Expenses.

- Profit and Loss account

- Operation Statement, etc.

Profit and Loss account is an explanation of impact of Profit-seeking Operations on shareholder's equity. The statement of profit and loss account is the condensed and classified record of the gains or losses causing changes in the owner's interest in the business for a period of time.

A comparison of earnings and expenses incurred in the earning of those incomes is made in this statement and the difference between the two is known as Net Profit and Loss. The Indian Companies Act 1956 fails to prescribe any legal Performa for profit and loss account, as it has prescribed for balance sheet. Profit and Loss account in the statement can be prepared in two ways for the purpose of analysis. They are:

a) Single step form.

b) Multi step method.

\subsection{STATEMENT OF THE PROBLEM:}


There are various views with respect to whether the traditional measures or value based measure is good for a firm's performance evaluation. In respect to BHEL-EPD how can their investors ascertain that whether the firm has created value for their investment or not and also to find out that the value created by the firm has grown or decline over a period.

\subsection{OBJECTIVES OF THE STUDY:}

- To compare and evaluate the different methods of shareholder value creation.

- To study about the investment value of business, credit rating and testing the efficiency of the operations.

- To analyze and come across many practical aspects and functioning of the organization.

- To analyze the practical and theoretical view of the organization.

- To overview the financial position and economic value addition of the company.

- To identify the factors affecting the financial and operational performance.

\section{Scope Of The Study:}

Scope of the data in general term means the extent to which it is possible to cover the subject, this study attempts to cover almost all the tools and techniques for the purpose of evaluating the financial dialectics of BHEL.

- Various ratios of different categories like liquidity ratio, activity ratio, leverage ratio and profitability ratio are calculated to know the financial soundness of the company.

- Time series or trend analysis is done to know the performance of the company over a number of years, in the study, trend is calculated.

- Competitive financial statements are having been prepared in order to facilitate comparison of the various elements of the financial statement for two or more period.

- Common size financial statement has been prepared to know the percentage of each item with their respective total.

- Finally each flow statements has been prepared to know the inflows and outflows of cash, which will in terms show the cash position of the firm.

EVA can be used for the following purposes:

- $\quad$ Setting organizational goals.

- Performance measurement.

- Determining bonus.

- Communication with shareholders and investors.

- Motivation of managers.

- Capital budgeting.

- Corporate budgeting.

- Corporate valuation.

\subsection{NEED FOR THE STUDY:}

The study is required for the following purpose:

TRADE CREDITORS: Trade creditors are interested in the firm ability to meet their claim over a short period of time; the project work will provide information on the firm's liquidity position.

SUPPLIERS OF LONG-TERM DEPOSITS: Suppliers of long term deposits are concerned with firms long term solvency and survival, the study will provide information about profitability over time, its ability to generate cash repay loans and also its capital structure.

INVESTORS: Investors who have invested their money in the form of shares are concerned with the firm's earnings; the study will present the firm's ability, risk and dividend payment pattern.

MANAGEMENT: Management of the firm would be interested in every aspect of the financial performance, it is their responsibility to see that resources of the firm are used efficiently and that financial condition is sound, this study will provide sufficient information to the management.

\subsection{RESEARCH METHODOLOGY:}

Research methodology involves preparation of broad action plan or blue print of this study, this is mainly inhouse research and includes the following:

\subsubsection{Sampling procedure:}


For the study, primary data is of little relevance, data availability is quite easy and the quality of available data is very reliable because the data are from the published information, i.e.; annual reports of the company, primary data is collected for this purpose, standard literature was abundant for the study.

Secondary data has been collected from the annual reports over the period of five years, from 2006 to 2010, which acts as a sample for the purpose of financial dialectics.

\subsubsection{Sources of data:}

As the data is related to the analysis and interpretation of financial performance, there was no necessary to collect the structured data for this study. Primary data and secondary data were used and collected from various sources.

Following are the sources of Primary data:

- Five years annual report of BHEL.

- Informal interviews with official of the company.

- Corporate and industry profile from the company's brochure and magazines.

\subsubsection{TOOLS USED FOR FINANCIAL DIALECTICS:}

I. Comparative financial statements.

II. Common size statements.

III. Cash flow statements.

IV. Ratio analysis.

V. Economic Value Addition.

Secondary data: secondary data was used mainly for the major study purpose which consists of annual reports of the company and its articles, company website and old project reports.

\subsubsection{Period of the study:}

The research is done on the data of 5 financial years, ie; from 2006-07 to 2010-11. As to find a clear analysis of the study five years of the company is considered for the research.

\section{Limitations of the study:}

- The financial dialectics and economic value added of the company has been done on the basis of the information contained in the financial statements; therefore this study is not able to predict the future performance of the company, only past performance is evaluated.

- This study is based on the financial data, without taking economy into consideration. Many changes like price level change and technological change might have taken place during the past five years; therefore this study may not reflect the actual performance of the company.

- Various accounting statistical tools extremely used for the present study have their own limitations. Thus findings of the present study should be used judiciously and carefully taken into account of the various limitations.

\subsubsection{HYPOTHESIS OF THE STUDY:}

As this is a financial performance study, no assumptions are required. This is clearer about the financial position of the BHEL from various financial statements like profit and loss account, balance sheet and retained earnings. A hypothesis is a supposition made as a basis for reasoning.

\section{RATIO ANALYSIS}

The ratio refers to the numerical or quantitative relationship between two variables or items, a ratio is calculating by dividing one item of relationship with the other. The need for the ratio arises due to the fact that absolute figures are often misleading, absolute figures are certainly valuable, but their value increases manifold if they are studied with another through ratio analysis. Ratio enables the mass of data to be summarized and simplified; ratio analysis is an instrument for diagnosis of the financial health of an enterprise. Ratios in fact are full of meaning and communicate the relative importance of the various items appearing in the balance sheet and profit and loss account.

The company's financial information is contained in balance sheet and profit and loss account. The figures contained in these statements are absolute and sometimes unconnected with one another. An absolute figure does not convey much meaning.

Ratio analysis is a tool of financial analysis. It can be used to compare the risk and return relationship of firms of different sizes. It is defined as the systematic use of ratio to interpret the financial statements so that the strengths and weakness of a firm as well as historical performance and current financial condition can be 
A Comparative Study of Financial Dialectics and E VA vs. Traditional Profit based measures-BHEL

determined.

The term ratio refers to the numerical or quantitative relationship between two items or variables. This relationship can be expressed as (a) percentages (b) fractions (c) proportions of the numbers, these alternative methods of expressing items which are related to each other are, for purpose of financial analysis, referred to as ratio analysis.

The need for ratio arises due to the fact that absolute figures are often misleading, absolute figures are certainly valuable, but there are value increases manifold if they are studied with another through ratio analysis, ratio enables the mass of data to be summarized and simplified, ratio analysis is an instrument for diagnosis of the financial health of an enterprise.

\section{BASIS OF COMPARISION:}

Ratios are relative figures reflecting the relationship between variables, they enables analyst to draw conclusion regarding financial operations. The use of ratios, as a tool of financial analysis, involves their comparison for a single ratio like absolute figures, fails to reveal the true position.

Comparison with related facts is, therefore the basis of ratio analysis, four types of comparison are involved:

(a) Trend ratios.

(b) Inter firm comparison.

(c) Comparison of items within a single year's financial statement of a firm.

(d) Comparison with standards and plans.

\section{MODE OF EXPRESSION:}

- RATE

- PURE RATIO OR PROPORTION.

- PERCENTAGES.

\section{The major classification of ratios is as follows:-}

\section{CURRENT RATIO}

Current ratio is the most common ratio for measuring liquidity, being related to working capital analysis it is also called as working capital ratio. It expresses the relationship between the current assets and current liabilities. The current ratio is the ratio of total current assets to the total current liabilities. It is calculated by dividing current assets by current liabilities, i.e.

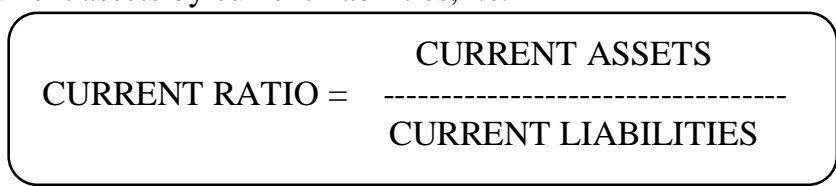

Formula no: 3.1 Computation of current ratio

\begin{tabular}{|l|c|c|c|c|c|}
\hline PARTICULARS & $\begin{array}{c}\mathbf{2 0 1 0 -} \\
\mathbf{1 1}\end{array}$ & $\mathbf{2 0 0 9 - 1 0}$ & $\begin{array}{c}\mathbf{2 0 0 8} \\
\mathbf{0 9}\end{array}$ & $\mathbf{2 0 0 7 - 0 8}$ & $\begin{array}{c}\mathbf{2 0 0 6} \\
\mathbf{0 7}\end{array}$ \\
\hline CURRENT ASSETS & 103.8 & 82.58 & 65.34 & 48.93 & 50.83 \\
\hline $\begin{array}{l}\text { CURRENT } \\
\text { LIABILITIES }\end{array}$ & 126.75 & 109.52 & 100.14 & 69.18 & 44.7 \\
\hline CURRENT RATIO & 0.819 & 0.754 & 0.652 & 0.707 & 1.137 \\
\hline
\end{tabular}

Table no: 3.1 Computation of current ratio of BHEL-EPD for 5 years

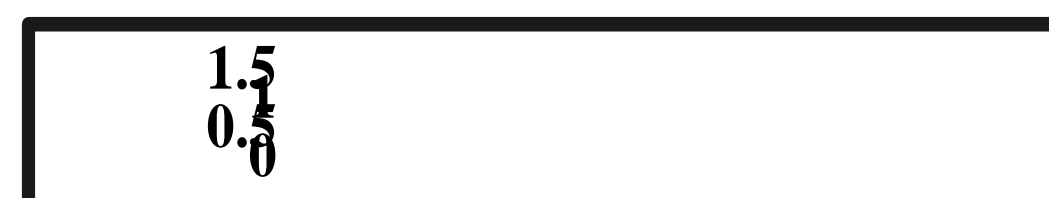

曰

Graph 3.1: Graphical representation of the current ratio

Interpretation: From the above graph, we can see that the curretn ratio of the company is fluctuating year by 
A Comparative Study of Financial Dialectics and E VA vs. Traditional Profit based measures-BHEL year, even though the ideal current ratio is $2: 1$, the company maintained a comparative good ratio, current ratio shows the company's ability to maintain the current asserts over its current laibilities.

\section{Quick Ratio}

Quick ratio is also known as liquid ratio or acid test ratio or near money ratio. It is the ratio between quick ratio or liquid assets and quick liabilities. Quick ratio refers to current assets which can be converted into cash immediately, it comprises all current assets minus stock and prepaid expenses and all current liabilities minus bank over draft. It can be calculated as:

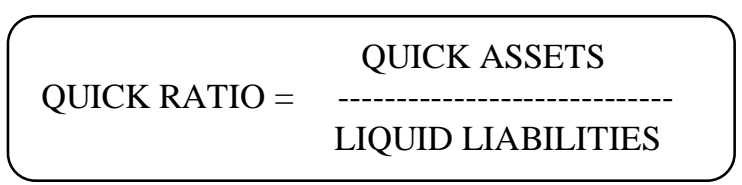

Formula no: 3.2 Computation of Quick ratio

\begin{tabular}{|l|c|c|c|c|c|}
\hline PARTICULARS & $\mathbf{2 0 1 0 - 1 1}$ & $\mathbf{2 0 0 9 - 1 0}$ & $\mathbf{2 0 0 8 - 0 9}$ & $\mathbf{2 0 0 7 - 0 8}$ & $\mathbf{2 0 0 6 - 0 7}$ \\
\hline QUICK ASSET & 103.8 & 82.58 & 65.34 & 48.93 & 50.83 \\
\hline LIQUID LIABILITY & 126.75 & 109.52 & 100.14 & 69.18 & 44.7 \\
\hline QUICK RATIO & 0.8189 & 0.7540 & 0.6524 & 0.7072 & 1.1371 \\
\hline
\end{tabular}

Table no: 3.2 Computation of Quick ratio of BHEL-EPD

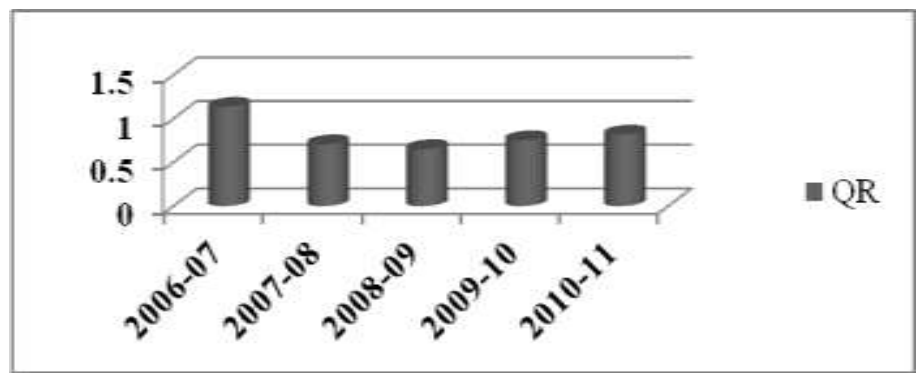

Graph no: 3.2: Graphical representation of quick ratio

Interpretation: From the above table and chart shows the relationship between the company's quick assets and quick liabilities, current year the ratio went down least compared to other years, but last year it went up to 1.1371 , is the highest in the last 4 years.

\section{Debt-Equity Ratio}

The relationship between borrowed funds and owner's capital, it is a popular measure of the long term financial solvency of a firm, this relationship is shown by debt equity ratio, this ratio indicates the relative proportions of debts and equity in financing the assets of a firm. It is calculated as:

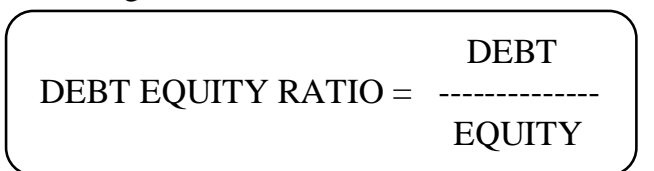

Formula no: 3.3 Computation of Debt-Equity Ratio

\begin{tabular}{|l|c|c|c|c|c|}
\hline PARTICULARS & $\mathbf{2 0 1 0 - 1 1}$ & $\mathbf{2 0 0 9 - 1 0}$ & $\mathbf{2 0 0 8 - 0 9}$ & $\mathbf{2 0 0 7 - 0 8}$ & $\mathbf{2 0 0 6 - 0 7}$ \\
\hline DEBT & 64.16 & 57.46 & 44.88 & 26.43 & 29.98 \\
\hline EQUITY & 55.06 & 21.47 & 15.35 & 15.17 & 20.09 \\
\hline DEBT EQUITY RATIO & 1.1652 & 2.6762 & 2.9237 & 1.7422 & 1.4922 \\
\hline
\end{tabular}

Table no: 3.3 Computation of debt-equity ratio 


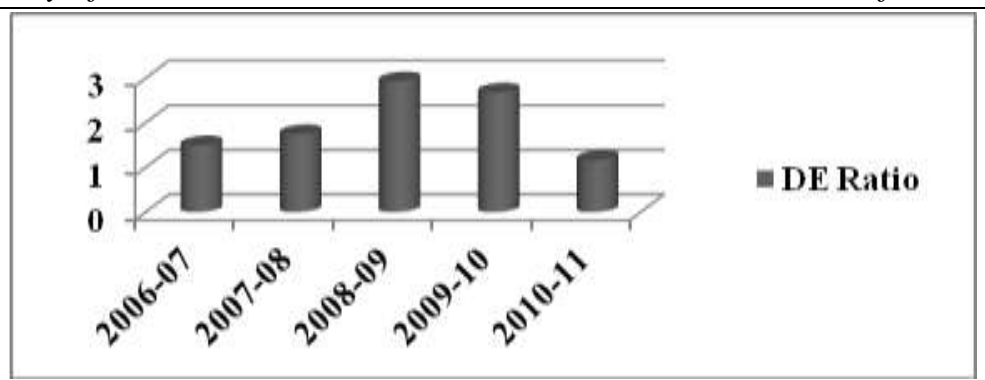

Graph no: 3.3 Graphical representation of debt-equity ratio

Interpretation: The above information about debt equity ratio shows that in the company not borrowed funds from outside, but in the last two years, company has played well with those funds. The ratio increases this year compare to that of the last year, but the borrowings decreases slightly in the last two years. Its better always to use borrowed funds compared to owned funds to a certain limit, by playing with borrowed funds we can increase the value addition of the company as well as shareholder's fund.

\section{Proprietary Ratio}

Proprietary ratio relates the shareholders fund to total assets, it is a variant of the debt equity ratio, and this ratio shows the long term future solvency of the business. The acceptable norm of the ratio is 1:3, the ratio shows the general strength of the company, it's an important ratio to creditors. It is calculated as:

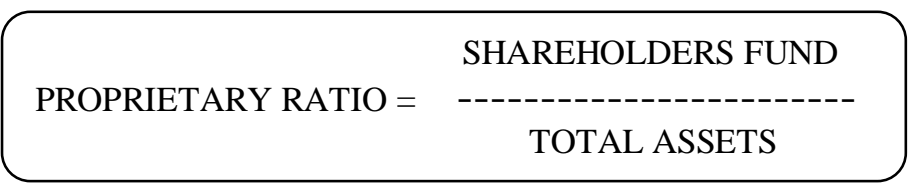

Formula no: 3.4 Computation of Proprietary ratio

\begin{tabular}{|l|c|c|c|c|c|}
\hline PARTICULARS & $\mathbf{2 0 1 0 - 1 1}$ & $\mathbf{2 0 0 9 - 1 0}$ & $\mathbf{2 0 0 8 - 0 9}$ & $\mathbf{2 0 0 7 - 0 8}$ & $\mathbf{2 0 0 6 - 0 7}$ \\
\hline SHAREHOLDERS FUND & 55.06 & 21.47 & 15.35 & 15.17 & 20.09 \\
\hline TOTAL ASSET & 103.80 & 82.58 & 65.34 & 48.93 & 50.83 \\
\hline PROPRIETARY RATIO & 0.530 & 0.260 & 0.235 & 0.310 & 0.395 \\
\hline
\end{tabular}

Table no: 3.4 Computation of proprietary ratio

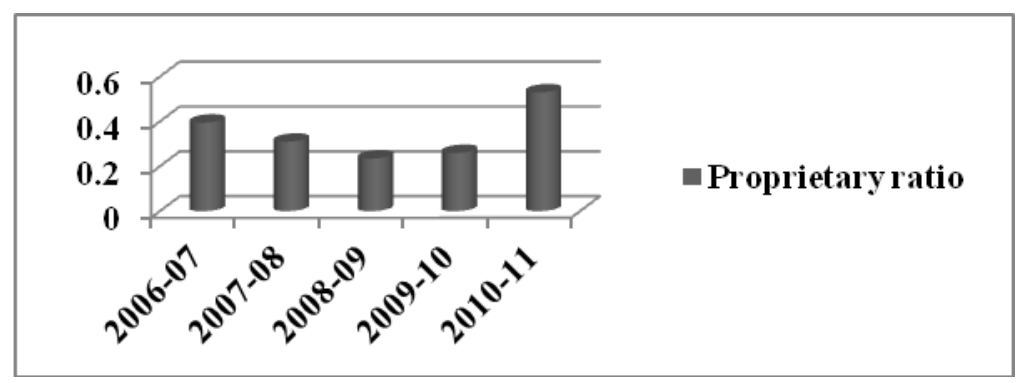

Graph no: 3.4: Graphical representation of proprietary ratio

Interpretation: This ratio is used to calculate the shareholders' value in the company, by looking into the above graph, we can say that the proprietary ratios is increasing and decreasing year by year, it is the comparison between the shareholders fund and total assets of the company, we can say that the company is used borrowed funds in the last two years, so usually the ratio will decrease but the value addition of the company as well as shareholders will increase.

\section{Solvency Ratio}

It is known as the debt ratio. This ratio is found out between total assets and external liabilities of the company. External liabilities mean all the short term and long term liabilities of the company. Solvency generally refers to the capacity or ability of the business to meet its short term and long term obligations. It measures the proportion of total assets provided by the firm creditors. A company is solved if it cannot meet its outside liabilities out of its total assets. 
A Comparative Study of Financial Dialectics and E VA vs. Traditional Profit based measures-BHEL It can be calculated as:

\begin{tabular}{|l|}
\hline SOLVENCY RATIO $=$ \\
\hline TOTAL LIABILITIES \\
\hline TOTAL ASSETS
\end{tabular}

Formula no: 3.5 Computation of Solvency ratios

\begin{tabular}{|l|c|c|c|c|c|}
\hline PARTICULARS & $\mathbf{2 0 1 0 - 1 1}$ & $\mathbf{2 0 0 9 - 1 0}$ & $\mathbf{2 0 0 8 - 0 9}$ & $\mathbf{2 0 0 7 - 0 8}$ & $\mathbf{2 0 0 6 - 0 7}$ \\
\hline TOTAL LIABILITIES & 126.75 & 109.52 & 100.14 & 69.18 & 44.7 \\
\hline TOTAL ASSET & 103.80 & 82.58 & 65.34 & 48.93 & 50.83 \\
\hline SOLVENCY RATIO & 1.221 & 1.326 & 1.533 & 1.414 & 0.88 \\
\hline
\end{tabular}

Table no: 3.5: Computation of solvency ratio

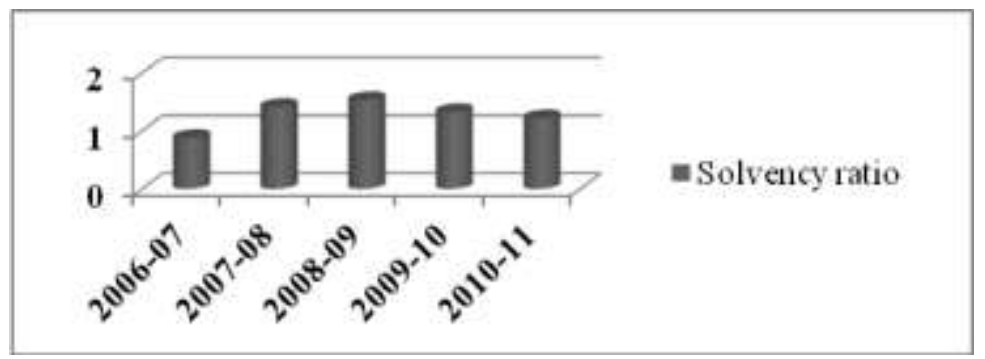

Graph no: 3.5 Graphical representation of solvency ratio

Interpretation: From the above table and chart we can say that the solvency ratio of the company is decreased when compared to the previous years. It shows the relationship between the total assets and total liabilities of the company. Solvency shows the companies capacity or ability of the business to meet its short term and long term obligations usually creditors are interested in these ratios.

VII. $\quad$ Fixed Asset To Net Worth Ratio

The ratio establishes between the fixed assets and shareholders fund. The ratio is fixed asset to net worth indicates the extent to which the shareholders fund are sunk into fixed asset, it the ratio is less than $100 \%$ it implies that owners fund are more than total fixed asset and a part of working capital is provided by the shareholders. $60-75 \%$ is considered to be the satisfactory ratio in case of industrial undertakings.

It can be calculated as:

\begin{tabular}{|cc|}
\hline FIXED ASSET TO NET WORTH RATIO $=$ & FIXED ASSET AFTER DEPRECIATION \\
\hline SHARE HOLDERS FUND
\end{tabular}

Formula no: 3.6 Computation of fixed asset to net worth ratio

\begin{tabular}{|l|c|c|c|c|c|}
\hline PARTICULARS & $\mathbf{2 0 1 0 - 1 1}$ & $\mathbf{2 0 0 9 - 1 0}$ & $\mathbf{2 0 0 8 - 0 9}$ & $\mathbf{2 0 0 7 - 0 8}$ & $\mathbf{2 0 0 6 - 0 7}$ \\
\hline FIXED ASSET & 8.21 & 9.26 & 10.3 & 11.92 & 12.68 \\
\hline SHAREHOLDERS FUND & 55.06 & 21.47 & 15.35 & 15.17 & 20.09 \\
\hline FIXED ASSET TO NET WORTH RATIO & 0.1491 & 0.4312 & 0.6710 & 0.7857 & 0.6311 \\
\hline
\end{tabular}

Table no: 3.6 Computation of fixed asset to net worth ratio

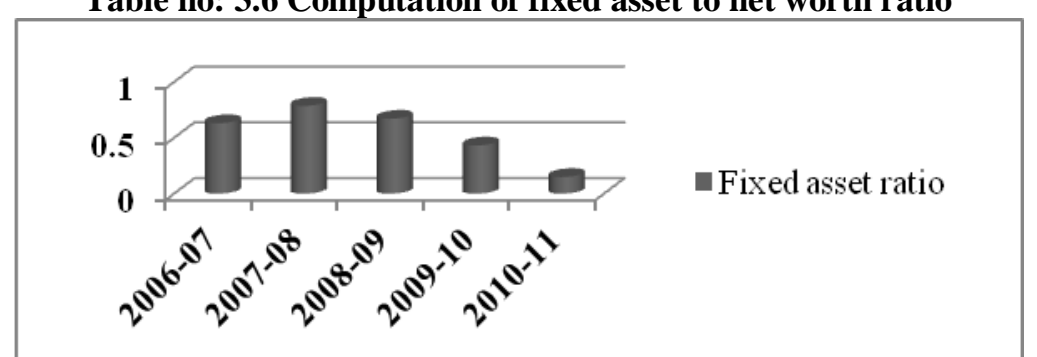

Graph no: 3.6 Graphical representation of fixed asset to net worth ratio

Interpretation: From the above information fixed asset to net worth ratio of the company is increasing stage, in 2004-05,2005-06 the ratio is constant but it is changing in the last two years actually it is calculating by dividing 
A Comparative Study of Financial Dialectics and E VA vs. Traditional Profit based measures-BHEL the amount of fixed assets after depreciation with shareholders fund.

VIII. Stock Turnover Ratio

This is also known as stock velocity. This ratio is calculated to consider the adequate of the quantum of capital and its justification of investment in inventory, this ratio helps the financial manager to evaluate the inventory policy. This ratio reveals the number of times finished stock is turned over during a given accounting period, and is used for measuring the profitability. The inventory turnover ratio measures how quickly inventory is sold. It is the test of efficiency inventory management. It can be calculated as:

\begin{tabular}{|c|c|c|c|c|c|}
\hline \multicolumn{2}{|c|}{ STOCK TURN OVER RATIO } & \multicolumn{4}{|c|}{ COST OF GOODS SOLD/ NET SALES } \\
\hline \multicolumn{6}{|c|}{ Formula no: 3.7 Computation of Stock Turnover ratios } \\
\hline PARTICULARS & 2006-07 & 2007-08 & 2008-09 & 2009-10 & 2010-11 \\
\hline Cost of goods sold & 141.29 & 155.8 & 181.38 & 194.27 & 234.51 \\
\hline Average inventory & 18.05 & 22.11 & 27.89 & 23.88 & 23.9 \\
\hline Stock turnover ratio & 7.8 & 7.04 & 6.5 & 8.13 & 9.8 \\
\hline
\end{tabular}

Table no: 3.7: Computation of stock turnover ratio

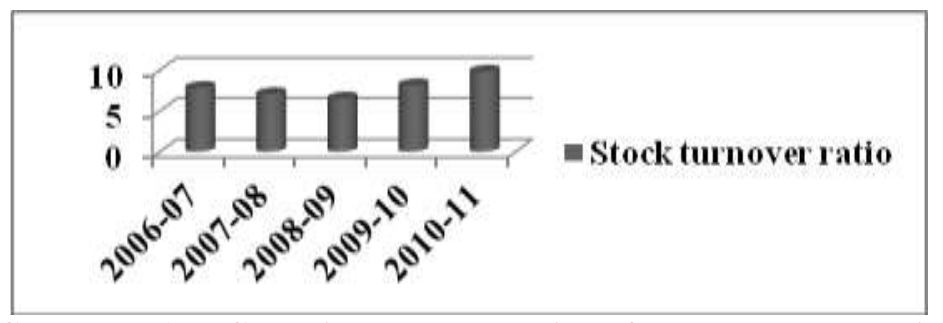

Graph no: 3.7: Graphical representation of stock turnover ratio

Interpretation: The stock turnover ratio of the company is in the decreasing stage for the $1^{\text {st }} 3$ years and then increased to 8.13 in the year 2009-10 and increased in the last year. A firm must have a reasonable stock comparison to sales, so here we can say that the company is managing its stocks and sales efficiently.

\section{Net Profit Ratio}

It is also called as net profit to the sales ratio the profit margin is indicative of management's ability to operate the business with sufficient success. Higher the ratio of the $m=$ net profit to the sales better is the operational efficiency of the company. This ratio is used to measure the overall profitability and hence it is very useful to proprietors, it is an index of efficiency and profitability when used with gross profit ratio and operating ratio. It can be calculated as:

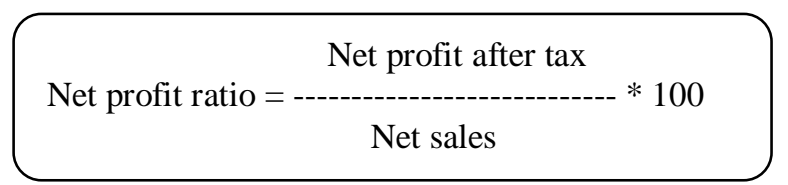

Formula no: 3.8 Computation of Net profit ratios

\begin{tabular}{|rr}
\hline & Net profit ratio \\
$\mathbf{4 0}$ & \\
$\mathbf{2 0}$ & Net profit ratio \\
$\mathbf{0}$ & \\
& \\
\hline
\end{tabular}

Graph no: 3.8: Graphical representation of net profit ratio 
A Comparative Study of Financial Dialectics and E VA vs. Traditional Profit based measures-BHEL

\begin{tabular}{|l|c|c|c|c|c|}
\hline PARTICULARS & $\mathbf{2 0 0 6 - 0 7}$ & $\mathbf{2 0 0 7 - 0 8}$ & $\mathbf{2 0 0 8 - 0 9}$ & $\mathbf{2 0 0 9 - 1 0}$ & $\mathbf{2 0 1 0 - 1 1}$ \\
\hline Net profit after tax & 12.44 & 11.07 & 11.75 & 17.87 & 51.46 \\
\hline Net sales & 139.38 & 162.46 & 183.24 & 201.26 & 251.55 \\
\hline Net profit ratio & 8.9 & 6.8 & 6.4 & 8.87 & 20.45 \\
\hline
\end{tabular}

Table no: 3.8 Computation of net profit ratio

Interpretation: In net profit ratio, the ratio has been decreased from 8.9 to 6.4 within two years and later again has increased by 8.87 and in last year it has drastically increased to 20.45 as the net profit after tax has increased from 17.87 to 51.46 . This shows that the company has incurred a huge profit in last year which is a good sign for the concern.

\section{COMPARATIVE FINANCIAL STATEMENTS:}

The preparation of comparative financial statements and operating statement is an important device of horizontal financial analysis, in these statements figures for two or more periods are placed side by side to facilitate comparison, these statements render comparison between two periods of time and exhibit the magnitude and direction of historical changes in the operating results and financial status of a business, financial statements of two or more firms are also be compared for drawing inference, the statement also provides for columns to indicate the change from one year to another in absolute terms and also in percentage form.

\section{OBJECTIVES:}

- To estimate the earning capacity of the firm.

- To decide about the future prospect of the firm.

- To know the progress of the firm.

- To judge the solvency of the firm.

- To measure the efficiency of the operations.

- To determine the debt capacity of the firm.

- To assess the financial position of the firm.

- To have comparative study.

- To help in making future plans.

PROCEDURE FOR INTERPRETATION:

- Ascertain the purpose and the extent of analysis and interpretation.

- Study the available data contained in financial statements.

- Get additional information if required.

- Arrange the data in the useful matter.

- Prepare comparative statement ratios.

- Interpret the facts revealed by the analysis.

- The interpretations drawn from the analysis are presented.

COMMON SIZE BALANCE SHEET FOR THE YEAR ENDING 2010-2011

(Figures in Rs. Crore)

\begin{tabular}{|l|c|c|c|c|}
\hline Particulars & $\mathbf{2 0 1 1}$ & $\mathbf{2 0 1 0}$ & Increase/ Decrease & $\begin{array}{c}\text { \% Increase/ } \\
\text { Decrease }\end{array}$ \\
\hline SOURCES OF FUNDS & & & & 0 \\
\hline Share capital & 489.52 & 489.52 & 0 & $21 \%$ \\
\hline Reserves and surplus & 19665.6 & 15406.5 & 4259.1 & $45.10 \%$ \\
\hline Loan funds & & & & \\
\hline Unsecured loans & 270.17 & 148.3 & 121.87 & \\
\hline Application of funds: & & & & $28.40 \%$ \\
\hline Fixed assets & & & & $47.43 \%$ \\
\hline Net block & 5812.47 & 4161.19 & 1651.28 & \\
\hline Capital work-in-progress & 11.3 & 5.94 & 5.36 & \\
\hline & & & & \\
\hline
\end{tabular}


A Comparative Study of Financial Dialectics and E VA vs. Traditional Profit based measures-BHEL

\begin{tabular}{|l|c|c|c|c|}
\hline Current assets & & & & \\
\hline Cash \& bank balances & 9706.4 & 9856.42 & -150 & $-1.50 \%$ \\
\hline Other current assets & 310.17 & 407.27 & -97.1 & $-31.30 \%$ \\
\hline Loans and advances & 3076.36 & 2662.18 & 414.18 & $13.46 \%$ \\
\hline $\begin{array}{l}\text { Less: current liabilities \& } \\
\text { provision }\end{array}$ & & & & \\
\hline Current liability & 31568 & 28211.2 & 3356.82 & $10.63 \%$ \\
\hline Provisions & 7620.36 & 4444.88 & 3175.48 & $41.67 \%$ \\
\hline Preliminary expenses & 3.76 & 2.36 & 1.4 & $37.23 \%$ \\
\hline & & & & $\mathbf{2 1 . 4 4 \%}$ \\
\hline TOTAL ASSETS & $\mathbf{2 0 4 2 5 . 3}$ & $\mathbf{1 6 0 4 4 . 3}$ & $\mathbf{4 3 8 0 . 9 7}$ & \\
\hline
\end{tabular}

CASHFLOW STATEMENT OF BHEL-EPD FOR LAST FIVE YEARS

\begin{tabular}{|c|c|c|c|c|c|c|}
\hline & & & & & Figures & Rs. Cro \\
\hline Description & & 2010-11 & 2009-10 & 2008-09 & 2007-08 & 2006-07 \\
\hline Cash Inflow (Operational) & & & & & & \\
\hline $\mathrm{REC} \triangle \mathrm{ACST} \triangle \mathrm{DV} / \mathrm{PD}$ & BHEL & $\begin{array}{c}--- \\
\end{array}$ & $\begin{array}{c}--- \\
-\end{array}$ & ---- & ---- & ---- \\
\hline KEC. AUS I ADV/PP & NON BHEL & 21.47 & 28.99 & 13.65 & 13.38 & 4.30 \\
\hline REC $\triangle G C T$ DESP & BHEL & 46.80 & 63.10 & 50.37 & 41.25 & 39.86 \\
\hline KEL.AUS I.DESP. & NON BHEL & 174.92 & 117.77 & 110.66 & 115.52 & 102.43 \\
\hline Export Incentives & & 0.40 & 0.06 & -- & -- & 0.21 \\
\hline Other Receipts & BHEL & 0.22 & & 0.71 & & \\
\hline & NON BHEL & 3.50 & 0.75 & 0.87 & 0.63 & 0.70 \\
\hline TOTAL INFLOW (OPER.) & BHEL & 47.2 & 63.10 & 51.08 & 41.25 & 39.86 \\
\hline & NON BHEL & 200.29 & 147.57 & 125.18 & 129.53 & 107.64 \\
\hline CASH OUTFLOW(OPERA & IONS) & & & & & \\
\hline Materials INDIG & BHEL & ---- & ---- & ----- & ----- & ----- \\
\hline & NON BHEL & 76.71 & 60.36 & 53.48 & 52.80 & 44.43 \\
\hline & IMPORTED & 5.13 & 4.37 & 5.97 & 3.54 & 2.34 \\
\hline Customs Duty & & 0.83 & ---- & 0.01 & ----- & ----- \\
\hline Payments & & 1.90 & 3.60 & 2.80 & 2.57 & 2.17 \\
\hline Personnel Payments & & 69.86 & 88.24 & 43.73 & 36.38 & 29.7 \\
\hline Sales Tax & & 4.17 & 0.23 & 0.53 & 2.22 & 3.46 \\
\hline Excise Duty/ Service Tax & & 4.36 & 6.53 & 8.36 & 5.73 & 12.82 \\
\hline Other Expenses & BHEL & 1.36 & 1.31 & 1.15 & 1.24 & 0.99 \\
\hline & NON BHEL & 50.83 & 37.00 & 41.18 & 37.83 & 31.14 \\
\hline Interest & BHEL & -2.57 & -0.31 & 0.06 & 0.83 & ----- \\
\hline & NON BHEL & 0.03 & ----- & ----- & ------ & ----- \\
\hline TOTAL OUTFLOW (OPR) & BHEL & -1.21 & 1.00 & 1.21 & 2.07 & 0.99 \\
\hline & NON BHEL & 213.82 & 200.33 & 156.06 & 141.07 & 126.06 \\
\hline SUR/(DEF)(OPR) & BHEL & 48.23 & 62.10 & 49.87 & 39.18 & 39.18 \\
\hline & NON BHEL & -13.53 & -52.76 & -30.88 & -11.54 & -18.42 \\
\hline CASH FLOW (NON OPER.) & & & & & & \\
\hline Capital Expenditure & & 0.64 & 1.37 & 1.27 & 1.49 & 3.22 \\
\hline Payment On Behalf Of Other. & & 3.35 & 3.66 & 4.13 & 2.72 & 3.07 \\
\hline IT/DIVIDEND SHARE/ OTH & $\mathrm{RS}$ & 5.11 & 8.60 & 8.25 & 4.64 & 1.60 \\
\hline TOTAL OUTFLOW (NON & PER.) & 9.10 & 13.63 & 13.65 & 8.85 & 7.89 \\
\hline OVERALL SURPLUS/ (DEF & ICIT) & 25.60 & -4.29 & 5.34 & 18.79 & 12.56 \\
\hline
\end{tabular}


A Comparative Study of Financial Dialectics and E VA vs. Traditional Profit based measures-BHEL

\section{Results and Discussions:}

Calculation of EVA for the year 2006

A. Computation of NOPAT:

\begin{tabular}{|c|c|}
\hline Particulars & Amount ( Rs. in Crores) \\
\hline EBT & 8.95 \\
\hline Interest expense & 0.05 \\
\hline EBIT & 9 \\
\hline Implied interest on operating exp/PV (note 4) & 100.3 \\
\hline NOP & 109.3 \\
\hline Cash operating taxes (NOTE 1) & 51.4 \\
\hline NOPAT & 57.9 \\
\hline
\end{tabular}

Interpretation: In the above table, interest expenses are added to the EBT (Earnings before tax) in Order to arrive at EBIT (Earnings before interest and tax), further the implied interest on operating expenses are added to arrive at NOP (Net operating profit), whose calculation is shown in note 4 below, then the cash operating taxes, calculation shown in note 1), are deducted from NOP to arrive at NOPAT (Net Operating Profit after Tax).

Note 1:

Cash operating taxes

\begin{tabular}{|c|c|}
\hline Particulars & Amount ( Rs. in Crores) \\
\hline Actual taxes given: Current & 16.23 \\
\hline Tax subsidy & 35.12 \\
\hline Cash operating taxes & $\mathbf{5 1 . 4}$ \\
\hline
\end{tabular}

Note 2:

Tax subsidy

\begin{tabular}{|c|c|}
\hline Particulars & Amount ( Rs. in Crores) \\
\hline Net interest expenses & 0.05 \\
\hline Implied interest on operating expenses/PV & 100.30 \\
\hline Tax rate & $35 \%$ \\
\hline Total & 100.35 \\
\hline Tax subsidy & $\mathbf{3 5 . 1 2}$ \\
\hline
\end{tabular}

Similarly NOPAT for last five years are as follows:

\begin{tabular}{|c|c|}
\hline Years & NOPAT ( Rs. in Crores) \\
\hline $2006-07$ & 57.9 \\
\hline $2007-08$ & 88.84 \\
\hline $2008-09$ & 98.7 \\
\hline $2009-10$ & 130.14 \\
\hline $2010-11$ & 181.4 \\
\hline
\end{tabular}

Graphical representation of NOPAT:

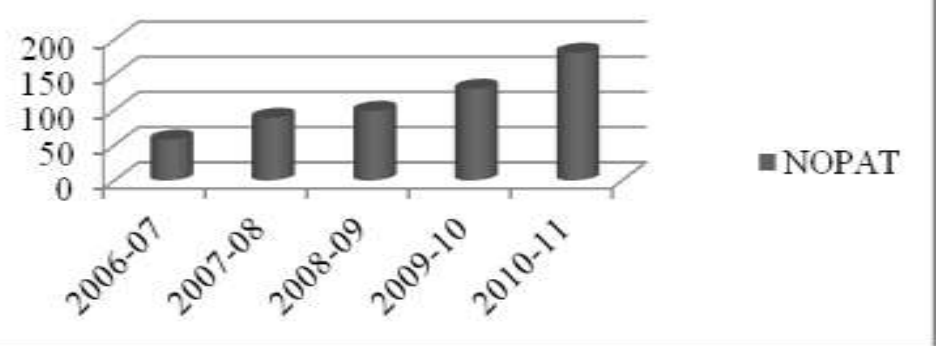

Interpretation:

From the above figure, it can be seen that the NOPAT is increased in the year 2006-07, i. e from 57.9 to 88.84 . Further in the year 2008-09 it reached to 98.7 and then to 130.14 in the year 2009-10 and again it's been increased to 181.14 in the year 2010-11. This shows the positive growth of the company as overall. It can be seen that the NOPAT is increasing each year, which is a very good progress in the firm's NOPAT.

A. Computation of cost of funds:

\begin{tabular}{|c|c|c|c|c|}
\hline Particulars & Amount (in Crs) & After tax cost (note 3) & weights & WACC \\
\hline Long term debt & 0.48 & 0.0677 & 0.0326 & 0.00220 \\
\hline Common stock(equity) & 1.80 & 0.0180 & 0.1222 & 0.00220 \\
\hline
\end{tabular}


A Comparative Study of Financial Dialectics and E VA vs. Traditional Profit based measures-BHEL

\begin{tabular}{|c|c|c|c|c|}
\hline Preference shares & - & - & - & - \\
\hline Retained earnings & 12.44 & 0.0026 & 0.845 & 0.002197 \\
\hline Total & $\mathbf{1 4 . 7 2}$ & & & $\mathbf{0 . 0 0 6 5 9 7}$ \\
\hline Cost of funds & & & & $\mathbf{0 . 0 9 7 1 0}$ \\
\hline
\end{tabular}

\section{Interpretation:}

The cost of funds is arrived by considering the various sources of funds available to the firm, like; Long term debt, equity, preference shares and retained earnings. Based on the amounts from different Sources of funds the weights are arrived and then they are multiplied with their respective after tax cost (calculation of after tax cost is shown in note 3 ) to derive the WACC (Weighted average cost of capital).

Similarly cost of funds for the last five years is as follows:

\begin{tabular}{|c|c|}
\hline Years & Cost of funds(in Crs) \\
\hline $2006-07$ & 0.09710 \\
\hline $2007-08$ & 0.3897 \\
\hline $2008-09$ & 2.6198 \\
\hline $2009-10$ & 0.1641 \\
\hline $2010-11$ & 13.1346 \\
\hline
\end{tabular}

Graphical representation of cost of funds:

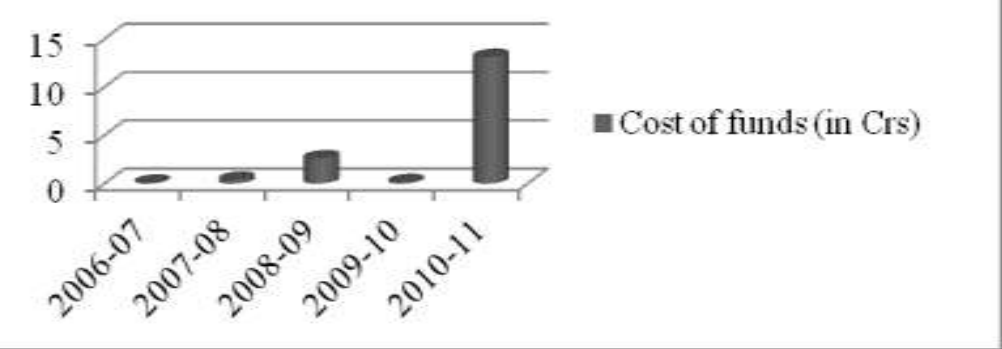

Interpretation: The cost of funds of the firm can be seen increasing from the year 2006-07 to 2007-08 from 0.09710 to 0.3897 and then increased to 2.6198 in the year 2008-09, but later year the cost of funds have been decrease to 0.1641 in the year 2009-10 thereafter the cost of funds have drastically increased to 13.1346 as the retained earnings has increased correspondingly. The increasing trend of cost of funds is not a prosperous sign for the firm's progress; it should always be kept very low for the smooth working of the firm. From the above figure we can see that till last year the cost was in a considerable manner but the Immediate last year the cost of funds should be reduced.

Note 3:

Calculation of after tax cost of debt

Cost of debt $\left(\mathbf{k}_{\mathrm{d}}\right)=$ Interest $(1-$ Tax $) /$ Debt

(Figures in Rs. Crore)

\begin{tabular}{|c|c|}
\hline Long term debt & 0.87 \\
\hline Interest & 0.07 \\
\hline Tax & $35 \%$ \\
\hline 1 -tax & $65 \%$ \\
\hline Cost $\left.\mathbf{~ k}_{\mathbf{d}}\right)$ & $\mathbf{5 . 2}$ \\
\hline
\end{tabular}

Note 4:

Capitalization of debt/equity equivalent

\begin{tabular}{|c|c|c|c|c|}
\hline Years & Operating lease & PV factor & PV of operating lease & PV \\
\hline $2006-07$ & 247.31 & 0.08 & 0.925 & 228.76 \\
\hline $2007-08$ & 210.67 & & 0.857 & 180.54 \\
\hline $2008-09$ & 176.26 & & 0.793 & 139.77 \\
\hline $2009-10$ & 170.78 & & 0.735 & 125.52 \\
\hline $2010-11$ & 147.50 & & 0.680 & 100.3 \\
\hline & $\mathbf{9 5 2 . 5 2}$ & & $\begin{array}{c}\text { Implied interest on operating } \\
\text { expenses/PV }\end{array}$ & $\mathbf{7 1 4 . 8 9}$ \\
\hline
\end{tabular}

Interpretation: the capitalization of debt/equity is necessary to find out because the Economic Value Added is calculated from the shareholders point of view. Therefore the actual cost borne by the Shareholders are to be found in all respect considered for calculating the EVA. In the table, the Operating lease which is a cost borne 
A Comparative Study of Financial Dialectics and E VA vs. Traditional Profit based measures-BHEL by the shareholders for future years are also considered by taking its present value and implied interest on operating expenses are arrived which is included in the calculation of NOPAT.

\section{RESULTS:}

\section{Calculation of EVA:}

EVA $=$ NOPAT - Cost of funds.

(Figures in Rs. Crore)

\begin{tabular}{|c|c|}
\hline NOPAT & 57.9 \\
\hline Cost of funds & $\mathbf{0 . 0 9 7 1 0}$ \\
\hline EVA & $\mathbf{5 7 . 8 0 2 9}$ \\
\hline
\end{tabular}

Interpretation: The EVA (Economic Value Added) is arrived by deducting cost of funds from the NOPAT. That is so because, all costs involved are to be deducted from the Net Operating Profit Available after tax in order to arrive at the actual funds available.

Similarly EVA for the last five years is as follows:-

\begin{tabular}{|c|c|c|c|}
\hline Years & NOPAT & Cost of funds & EVA \\
\hline $2006-07$ & 57.9 & 0.09710 & 57.8029 \\
\hline $2007-08$ & 88.84 & 0.3897 & 88.4503 \\
\hline $2008-09$ & 98.7 & 2.6198 & 96.0802 \\
\hline $2009-10$ & 130.14 & 0.1641 & 129.9759 \\
\hline $2010-11$ & 181.14 & 13.1346 & 168.00 \\
\hline
\end{tabular}

\section{Graphical representation of EVA}

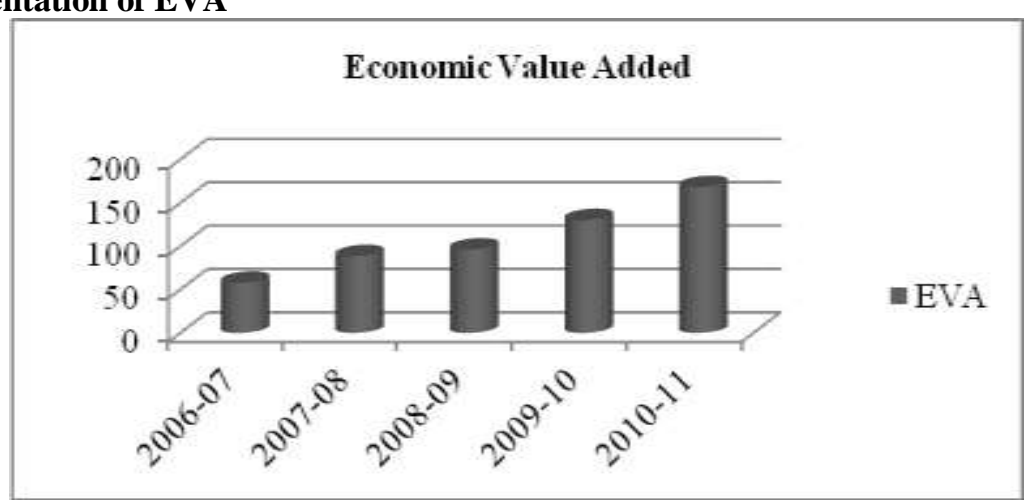

Interpretation: The firm's EVA can be seen increasing year by years in a consistent manner ie; from 2006-07 to 2010-11. It has been increasing from 57.80 to 88.450 in the year 2007-08further it has been increased to 96.0802 in the year 2008-09 and then increased to 129.97 in the year 2009-10 and further again increased to 168.00 from 129.97 in the year 2010-11. The overall performance is very good as the EVA for the years are positive and is in the increasing trend. The challenge is to maintain the EVA positive which the firm has been succeeded to do over the past five years.

Calculation of EVA Growth:

Growth/decline for $2010=$ EVA of $2010 /$ EVA of 2009

Similarly growth/decline of EVA for last five years, ie; from 2006-07 to 2010-11 as per above calculation methods are as follows:-

\begin{tabular}{|c|c|c|}
\hline Years & EVA (Figures in Rs. Crore) & Growth/Decline \\
\hline $2007-08$ & 88.4503 & $153.02 \%$ \\
\hline $2008-09$ & 96.0802 & $108.62 \%$ \\
\hline $2009-10$ & 129.9759 & $135.27 \%$ \\
\hline $2010-11$ & 168.00 & $129.26 \%$ \\
\hline
\end{tabular}

Table 4.11 Growth/Decline of EVA of five years

\section{Interpretation:}

Over the years, that is, from 2007 to 2010, the EVA of the firm has been decreased in the year 2008 ie; from $153.02 \%$ to $108.62 \%$ and then increased in the year 2009 to $135.27 \%$ and again decreased to $129.26 \%$ in the year 2010-11.

There is a decrease in the EVA percentage as its not a positive signal for the firm as well as the shareholders, but it should also be noticed that the EVA has declined but not gone negative which is a favorable sign for the company. 


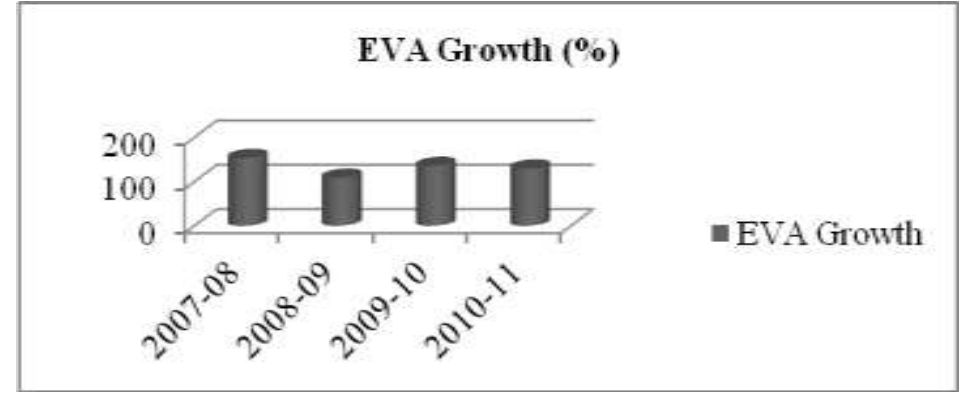

Figure: 4.3 Graphical representations of EVA Growth / Decline

\section{Conclusion:}

- The researcher would like to thank BHEL-EPD division being a public sector company they have been more cooperative, good amount of information was shared. BHEL-EPD is doing well in the present market. In each department EPD has managed the functions efficiently and successfully.

- BHEL has been selected as one of the navarathna public units by government of India. The unit has been very good safety and security provisions and it is accredited with Eco-friendly policies.

- From the study "A study on financial dialectics and economic value added" of BHEL-EPD division, Bangalore" we could understand that EVA framework has reflected the right value creation, motivate the right behavior, produce consistent and definitive results than any other analysis. Traditional measure of corporate performance assumes that there is no charge on equity. Dividends come out of profits, and if a company does not make a profit, it can skip paying out dividends. Thus, shareholders accept at least a market rate of return when they buy a company's share. The result of the study shows that is is very difficult to generate the basic content of awareness based on these studies. Other studies in this respect do not elicit different results and present the vastly different orientation or sets.

- The researcher would like to conclude that, this unit (BHEL-EPD) even though its facing some ups and down in its overall performance, BHEL-EPD is doing well in the present market and posses good and highest market share compared to its competitors. The employees are provided with very good facilities and has very good working environment and work culture which in turn making better profits year by year.

- The company is trying to increase the profits by setting up new targets and implementing the new projects, they have also planned to go for semi automation which will ease the working condition for workers without affecting the present job.

- The turnover of the company has touched a growth of $10 \%$ an average throughout the year. The company has good financial planning as a result it has good financial position and also good market leadership in spite of heavy competitions.

\section{Summary of the study:}

- The study entitled "Financial dialectis and Economic Value Addition" has been undertaken with the objective to analyze and interpret the BHEL-EPD financial performance.

- The researcher can conclude that the company has made a distinctive profit for the past five years and performing well irrespective of the changing conditions and problems. In general, BHEL-EPD has achieved a tremendous progress and has been able to achieve high growth across multiple parameters including geographical spread, business volumes and revenues.

- Creating shareholder value is a fundamental requirement for all the companies. Therefore most of the leading companies adopt a mantra of shareholder value to meet the increasing expectations of the shareholders. Academicians, professionals do not give importance for EVA and some of the factors are considered for the investment decision. There is no specific factor, including EVA, based on which the investment decision should be made. The investors do not use all the available information.

- The investors depend more on readily available and easily computable measures such as EPS rather than complicated measures like EVA, as it requires a lot of adjustments and calculations, unlike other measures which can be easily calculated or available from the financial statements.

- However it cannot be ignored that EVA as a performance measure gives a clear and descriptive picture of the firm's financial performance and an investment decision can be supported based on EVA results. Seeing the performance of the company it can be concluded that the firm has been successful in creating shareholders wealth.

\section{FINDINGS:}


A Comparative Study of Financial Dialectics and E VA vs. Traditional Profit based measures-BHEL

- BHEL-EPD has a good hold in the market share of composite insulators.

- They have maintained a good industrial relation.

- Employees are knowledgeable, kind, helpful, informative and cooperative.

- EVA is a better measure of performance as it includes the various aspects in calculating the Value than the other performance measures, such as ROI, ROE, EPS, etc.

- The firm's EVA can be seen increasing from the year 2006-07 to 2010-11 ie; 57.80 crores, 88.45, 96.0802, 129.97 and 168.00 respectively. This shows the overall performance is very good as the EVA for the years are positive.

- Advertisement cost is less because they manufacture based on the orders.

- Good working environment with $300+$ trees in campus, which helps to reduce the pollution and water scarcity. A library which offers a vast range of books, journals, magazines, newspaper, intranet and internet facilities.

- Performance of the firm is good and steady in nature.

- The firm is very lucrative as it can provide better yield because it has been creating wealth for the shareholders on a continuous basis.

SUGGESTIONS \& RECOMMENDATIONS:

On the basis of the analysis, the following recommendations can be given:-

- Strictly advice the workers to use safety equipment at the shop floor which supports the slogan

"WORK SAFELY ALL THE WHILE; GO HOME WITH A HAPPY SMILE".

- Introduce new technology where in the excessive wastage after the kiln can be reduced.

- Provide sign boards at a conspicuous place to facilitate easy identification of the departments.

- A regular income for the investor can be expected as the company distributes dividend every year which could be found from the analysis.

- The firm should decrease its cost of funds in order to create more wealth for the Shareholders. As in the research it could be seen that the cost of funds has been increasing over the years.

- The firm should increase its operating profits by reducing the interest and other expenses because then only the Net operating profit after tax could be increased which is turn will help in creating the wealth for the shareholders.

ANNEXURE

Balance sheet of BHEL - EPD for five years:

\begin{tabular}{|c|c|c|c|c|c|}
\hline Particulars & Mar' 11 & Mar' 10 & Mar' 09 & Mar' 08 & Mar' 07 \\
\hline \multicolumn{6}{|l|}{ Sources of funds } \\
\hline \multicolumn{6}{|l|}{ Owner's fund } \\
\hline Equity share capital & 489.52 & 489.52 & 489.52 & 489.52 & 244.76 \\
\hline Share application money & - & - & - & - & - \\
\hline Preference share capital & - & - & - & - & - \\
\hline Reserves \& surplus & $19,664.32$ & $15,427.84$ & $12,449.29$ & $10,284.69$ & $8,543.50$ \\
\hline \multicolumn{6}{|l|}{ Loan funds } \\
\hline Secured loans & - & - & - & - & - \\
\hline Unsecured loans & 163.35 & 127.75 & 149.37 & 95.18 & 89.33 \\
\hline Total & $20,317.19$ & $16,045.11$ & $13,088.18$ & $10,869.39$ & $8,877.59$ \\
\hline \multicolumn{6}{|l|}{ Uses of funds } \\
\hline \multicolumn{6}{|l|}{ Fixed assets } \\
\hline Gross block & $8,049.30$ & $6,579.70$ & $5,224.43$ & $4,443.03$ & $4,134.61$ \\
\hline Less : revaluation reserve & - & - & - & - & - \\
\hline Less : accumulated depreciation & $4,648.82$ & $4,164.74$ & $3,754.47$ & $3,462.21$ & $3,146.31$ \\
\hline Net block & $3,400.48$ & $2,414.96$ & $1,469.96$ & 980.82 & 988.30 \\
\hline Capital work-in-progress & $1,762.62$ & $1,550.49$ & $1,212.70$ & 658.47 & 306.58 \\
\hline Investments & 439.17 & 79.84 & 52.34 & 8.29 & 8.29 \\
\hline
\end{tabular}


A Comparative Study of Financial Dialectics and E VA vs. Traditional Profit based measures-BHEL

\begin{tabular}{|c|c|c|c|c|c|}
\hline Particulars & Mar' 11 & Mar' 10 & Mar ' 09 & Mar ' 08 & Mar ' 07 \\
\hline Current assets, loans $\&$ advances & $61,214.87$ & $44,515.53$ & $38,743.86$ & $33,463.46$ & $25,239.99$ \\
\hline Less : current liabilities \& provisions & $46,499.95$ & $32,515.71$ & $28,390.68$ & $24,241.65$ & $17,665.57$ \\
\hline Total net current assets & $14,714.92$ & $11,999.82$ & $10,353.18$ & $9,221.81$ & $7,574.42$ \\
\hline Miscellaneous expenses not written & - & - & - & - & E \\
\hline Total & $20,317.19$ & $16,045.11$ & $13,088.18$ & $10,869.39$ & $8,877.59$ \\
\hline \multicolumn{6}{|l|}{ Notes: } \\
\hline Book value of unquoted investments & 439.17 & 79.84 & 52.34 & 8.29 & 8.29 \\
\hline Market value of quoted investments & - & - & - & I- & \\
\hline Contingent liabilities & $2,324.26$ & $2,538.13$ & $2,546.25$ & $1,673.19$ & 976.05 \\
\hline Number of equity shares outstanding (Lacs) & 4895.20 & 4895.20 & 4895.20 & 4895.20 & 2447.60 \\
\hline
\end{tabular}

\section{References:}

[1] Beaver W (1989); Financial Reporting: An Accounting Revolution; Englewood Cliffs, NJ; Prentice Hall

[2] Brealy R \& Myers S (1991); Principles of Corporate Finance 4th ed; New York; McGraw Hill

[3] Coates J B, Davies M L, Davis E W, Zafar A \& Zwirlein T (1995); Adopting performance measures that count: changing to a shareholder value focus; Aston Business School Research Paper No RP9510

[4] Coates J B, Davis E W, Longden S G, Stacey R J \& Emmanuel C (1993); Corporate Performance Evaluation in Multinationals; London; CIMA

[5] Coates J B, Davis E W \& Stacey R J (1995); performance measurement systems, incentive reward schemes and short - termism in multinational companies: a note; Management Accounting Research Vol 6 pp 125-13516

[6] Crowther D E A (1995a); Dimensions of corporate performance: towards a new evaluation paradigm; Proceedings of Second Research Colloquium; Henley; Henley-Nisbet; pp 57-69

[7] Crowther D E A (1995b); Institutionalism, determinism and rationality: the consequences of accounting for performance; paper presented at the Management Accounting Research Group Conference, Aston University, Sept 1995

[8] Crowther D E A (1996); Corporate performance operates in three dimensions; Managerial Auditing Journal; Vol 11 No 8 pp 4 -13

[9] Eccles R G (1991); The performance evaluation manifesto; Harvard Business Review; Vol 69 No 1 pp 131-137

[10] Ezzamel M \& Hart H (1987); Advanced Management Accounting: An Organizational Emphasis; London; Cassell

[11] Fisher F M \& McGowan J I (1983); On the misuse of accounting rates of return to infer monopoly profits; American Economic Review Vol 73 pp 82-97

[12] Govinderajan V \& Gupta A K (1985); Linking control systems to business unit strategy: impact on performance; Accounting, Organizations \& Society Vol10 No 1 pp 51-66

[13] Jensen M \& Meckling W (1976); Theory of the firm: managerial behaviour, agency costs and ownership structure; Journal of Financial Economics; October pp 305-360

[14] Journal of Applied Corporate Finance (1994); Stern Stewart EVA Roundtable; Volume 7 No.2, Summer, 46 -70.

[15] McDonald D \& Puxty A G (1979); An inducement - contribution approach to corporate financial reporting; Accounting, Organisations \& Society; Vol 4 No $1 / 2$ pp 53-65

[16] Monks R A G \& Minow N (1991); Power and Accountability; Glasgow; Harper Collins

[17] O"Hanlon J \& Peasnell K (1996); Measure for Measure; Accountancy; London

[18] Rappaport A (1986); Creating Shareholder Value; New York; The Free Press

[19] Rappaport A (1992); CFO"s and strategists: forging a common framework; Harvard Business Review May/Jun 1992 pp 84-91

[20] Solomons D (1965); Divisional Performance: Measurement and Control; London; Irwin.

[21] Stewart G B III (1991); The Quest for Value; New York; Harper Collins

[22] Stewart G B III (1994); EVA, fact and fantasy; Journal of Applied Corporate Finance; Vol 7 No 2 pp 71 -87

[23] Tinker T (1985); Paper Prophets: A Social Critique of Accounting; London; Holt, Rinehart \& Winston17

[24] Williamson O E (1963); A model of rational managerial behaviour; in Cyert R M \& March J G (eds); A Behavioural Theory of the Firm; Englewood Cliffs, NJ; Prentice-Hall 